\title{
The Effectiveness of Rational Emotive Behavior Group Counseling Against the Assertive Behavior of Students SMP N 1 Mlati, Sleman, Yogyakarta
}

\author{
Yulia Rahmatika Aziza \\ Graduate School \\ Universitas Negeri Yogyakarta \\ Yogyakarta, Indonesia \\ yuliarahmatika_aziz@yahoo.com
}

\author{
Edi Purwanta \\ Graduate School \\ Universitas Negeri Yogyakarta \\ Yogyakarta, Indonesia \\ edi_purwanta@uny.ac.id
}

\begin{abstract}
This study aimed to determine the effectiveness of rational emotive behavior group counseling against the assertive behavior of students SMPN 1 Mlati, Sleman, Yogyakarta. Rational emotive behavior group counseling has not been used for counseling process at SMPN 1 Mlati, Sleman, Yogyakarta. This research was a quantitative research with quasi experimental research design and randomized control group pretest-posttest design. The research subjects were taken by purposive sampling technique. Subjects of the study were 12 students from grade VII, VIII, and class IX who had low assertive behavior and were willing to attend group counseling sessions. Methods of data collection used assertive behavior scale. The data were analyzed using different test of Wilcoxon matched pairs signed rank test to know the difference of assertive behavior score between the experimental group and the control group. The result of the research showed that rational emotive behavior group counseling was not effective to improve the assertive behavior of students of SMPN 1 Mlati, Sleman, Yogyakarta. There were several factors that were suspected to be the cause of rational emotive behavior group counseling to be not effective against assertive behavior of students. These factors were relatively short time counseling and less conducive counseling sites, lack of interpersonal closeness between counselor and counselee, and other techniques that could also be used to improve student assertive behavior
\end{abstract}

Keywords- Rational emotive behavior group counseling, assertive behavior

\section{INTRODUCTION}

Student at junior high school which is in the transition period from children toward adulthood is at the stage of development of the duty teenagers. The term teenager known as "adolescence" which means to grow or develop into adulthood. The adulthood shows the developmental stages between children and adult, marked by a physical development changes, cognitive and social development. Teens usually differentiated into three namely early adolescence; $12-15$ years of age, middle adolescence; $15-18$ years of age and late adolescence; 18-21 years of age [1]. Based on expert opinion, adolescence is rapid change. Between the ages of 12 to 20 years, they have social, psychological, and rapid biology changes. Adolescence is a time of transition. Adolescence is a bridge that connects childhood and adult [2].

Adolescence is a period of transitions of children into adulthood. During this period, numerous changes occurred both hormonal changes, physical, psychological and social. This change is happening very quickly and sometimes without us even knowing. Early adolescence roughly lasts from age 13 to age 16-17 years. On early adolescence usually last only in relatively short time. During this period marked by negative traits on teenagers so often this period is called the negative period with symptoms such as not quiet, less like work, and pessimistic. Explained that in adolescence growing attitude of conformity i.e. the tendency to give up or keep opinions, opinions, values, habits, pastimes, or wishes of others its major peers. The socialization with peers has an important role in the formation of the personality of the adolescent [3].

One of behaviors that help the process of socialization with peer is assertive behavior. Explain that assertive is interpersonal behavior where each individual trust and honest to their self, be able to express the thoughts and feeling, as well as being able to exercise the rights personal verbal and nonverbal but not harming others [4]. While based on the opinion assertiveness is the characterization of how someone responding in situations where their interest in the position and may conflict with the position or interests of others [5].

Students of SMP 1 Sleman Yogyakarta Mlati has low assertive behavior of the data obtained from the results of interviews and observations with the counseling teacher at school and then did a preliminary study and showed that the low student assertive behavior was characterized with underprivileged students suggested, less bold reveal personal wishes or opinions in public, tend to withdraw when asked to join with peers, felt less comfortable when together with other friends considered incompatible with itself. 
Researchers perform advanced data networking by providing behavior scale assertive to 234 students in SMPN 1 Mlati, Sleman, Yogyakarta to strengthen the data observations and interviews. Students are given the scale of this is grade VII and VIII as well as most students of class IX recommended by the teacher. The teacher helped the researchers to give scale to the students at the school. The results of charging the scale showed there were 23 students have low assertive behavior, 73 students have moderate assertive behavior, 121 students have high assertive behavior and 17 students have high assertive behavior. The 23 students with low assertive behavior are consists of male and female students. They were taken randomly for the subject in the experiment group and control group. Researchers conducted the study on experimental group by using rational emotive behavior approach to know the results of counselling group rational emotive behavior assertive behavior towards the students of SMP 1 Mlati, Sleman, Yogyakarta. The formulation of the problem in this research was whether the counseling of the rational emotive behavior group is effective against assertive behavior students SMP 1 Mlati, Sleman Regency, Yogyakarta.

There has been no research that uses of counseling group rational emotive behavior techniques for student assertive behavior. Researchers are keen to test the effectiveness of the counseling group rational emotive behavior to the behavior of assertive with the aim to do irrational belief dispute and help cultivate a new feeling and followed by more rational behavior. Counseling group of rational emotive behavior have been widely used in previous studies e.g. in the case of bully, low self-esteem, adaptations etc. The results of the previous research stated that the behavior of the assertive effective for problems of the students in the school.

Ellis explains that the person's behavior emotions, feeling happy, sad, frustrated, all of these are not directly caused by the events experienced by the individual. There are many benefits with the counseling groups where learners would be it helpful to have more positive thoughts against yourself, lose the feeling of isolation, improves interpersonal relationships and increasing views or the orientation of the future. In addition to counseling the rational emotive behavior positively impact on behavior disorders, emotional disorders and other behavior [6]. The main goal of the counseling approach rational emotive behavior this is help individuals realize that they can live with more rational and more productive. Rational emotive behavior teaches the individual to correct the error of thinking to reduce unexpected emotions [7].

\section{THEORY}

\section{A. Rational Emotive Behavior Group Counseling}

Previous studies that support the existence of this research are: research conducted by Kumar describes the results of research about the benefits of counseling REBT. That research was experimental research design that aims to find out the benefits of granting counseling REBT on the realm of cognitive, emotive, and behavioral, to find out how techniques REBT in resolving problems on the individual. The counseling was given to experimental group for 7 sessions, within seven weeks. There are 10 groups, with 10 subjects in each group. The results of these studies revealed that REBT was able to reduce the symptoms of disorders of behavior and have a positive impact on behavior disorders and disorders of emotion.

The purpose of the counseling is trying to help the client to get some core attitude that can be used to free their self from the interference range of situations, not a matter of emotional behavior. The client supported to develop and implement an effective life philosophy [8]. In line with the opinion above, explains that the purpose of the counseling approach rational emotive behavior it is relieving the symptoms with more specific problems are cognitive, emotional, and such behavior anxiety, depression, avoiding social situations and public speaking. The purpose of the counseling process group rational emotive behavior is to allay irrational thoughts become more rational.

Conducts research on the effectiveness of rational emotive behavior therapy (REBT) to reduce student anxiety accelerated SMA Negeri 1 Batu. This research uses a pre-study method of experimentation with the design of the one group pretest - posttest. The subjects in the study consisted of 5 people who acquired anxiety scale results. Statistical nonparametric with different test Wilcoxon analysis techniques was used to analyze the data. The results of the study showed that rational emotive behavior therapy was effective to reduce the anxiety level students Accelerated SMA Negeri 1 Batu [9].

The research about rational emotive behavior therapy to troubled students who published in the journal reclaiming children and youth. The study shows the results of the discussions that the rational emotive behavior therapy can lead students towards a more rational thought process and encourage students to their success in daily activities [10].

Conducted a study with the title the impact of Rational Emotive Behavior Therapy (REBT) on conduct disorder in adolescent students. Such research is research using randomized experimental designs control group pretest-posttest. The research was enforced to the subject research of 200 male students and women who were divided into a control group and experiment group. The treatment was given as many as seven sessions to groups of experiments. The results showed that rational emotive behavior therapy was very effective in the treatment of disorders of behavior in teenagers. In addition, rational emotive behavior therapy was also effective on the issue of emotions and behavior deviates in teenagers [11]. 
That the described a group of techniques that yield rational emotive behavior managed to help school counselors to close the achievement gap, encouraging students enter college and encourage career readiness among students. Primarily are those who come from underrepresented populations historically. This means that the approach rational emotive behavior can deliver benefits to the school counselor to motivate students in the school [12].

The research about the use of rational emotive behavior group counseling therapy techniques homework to reduce aggressive behavior of the students at the grade 7 level. The research used quasi experiment method to the design of one group pretestposttest and using the Wilcoxon different test. The results showed that group counseling group of rational emotive behavior therapy using homework techniques was effective in reducing aggressive behavior of students with a score of $20.44 \%$ [13].

The success of those researches becomes one of the backgrounds and amplifier research taken. The various studies above explain that the counseling techniques of rational emotive behavior is capable to solve or help a wide range of problems of the students in school, reducing the sense of anxiety in students, eliminate irrational thoughts and fostering the rational mind and the driving spirit as an accomplished student.

Counseling of the rational emotive behavior group is counseling developed by Albert Ellis in the middle of the 1950s which emphasized the importance of the role of the mind in behavior. The rational emotive behavior approach is an approach that emphasizes the relationship between feelings, behavior and thoughts. Ellis explains that a person's behavior, especially emotions, feelings of pleasure, sadness, frustration, all these things are not caused directly by the events experienced by the individual. But those feelings are caused by the way humans think themselves or the belief system that is owned by the individual [14].

Rational emotive behavior counseling according to Ellis is based on the concept that thinking and feeling are interrelated, but more emphasized on the mind than one's emotional expression [15]. That there are three fundamental hypotheses as the basis for the Rational Emotive Behavior Therapy (REBT) approach, namely human thoughts and emotions are interrelated, thoughts and emotions usually influence each other, such as cause and effect relationships, thoughts and emotions tend to play a role in individual self-talk that will affect when modifying individual emotions [16].

The most important thing in group counseling with the rational emotive behavior approach is the counselor's skills to be able to challenge, confront, give confidence to the counselee to take action that will lead to constructive change [17].

Based on some expert opinions above, it can be concluded that the rational emotive behavior group counseling is the provision of dynamic group assistance, focusing on the feelings and thoughts of the counselee, namely on the irrational domains of emotions and thoughts and converted into more rational feelings and thoughts. In counseling rational emotive behavior groups there are stages in the counseling process. The counseling stage is [18]:

1) Phase 1, the counselee's awareness process of irrational thinking and reinforcement that the counselee has the potential to change

2) Phase 2, the rational mind dispute process and the implementation of counseling techniques

3) Phase 3, the process of developing a rational life philosophy

The Other opinion explain that the stages of counseling of rational emotive behavior groups are as follows [19]:

1) The first stage, the process of showing the client that he is illogical, helps to understand why they are so and shows the relationship of irrational disorder to the unhappiness and emotional disturbance experienced

2) The second stage helps clients believe that thinking can be challenged and changed. The client's willingness to be explored logically against the disruption experienced by the client and the counselor directs the client to do disputing against the irrational client's beliefs.

3) The third stage helps clients to "debate" (disputing) inappropriate or irrational disturbances that have been maintained so far towards a more rational way of thinking by means of rational reindoctrination including being rational.

\section{B. Assertive Behavior}

Understanding assertive behavior is a positive behavior which is an honest attitude, open directly. Assertive behavior does not appear on its own but needs to be nurtured to develop properly. Morganett, 1990 and Vernon, 1989 explain the notion of assertive behavior is to defend rights without violating the rights of others. Assertive behavior considers other people's feelings and not negative confrontations. Assertive behavior is the right expression of one's feelings, beliefs, and opinions.

Based on the opinion that children expressly state that what they feel without shame can express their needs clearly and they respect the rights of others to refuse. A child who is firm when unable to do something. Then it will improve his situation rather than blame others or blame himself [20].

The notion of assertive behavior is interpersonal behavior where everyone believes and is honest with himself, can express his thoughts and feelings, and is able to exercise personal rights verbally and nonverbally but does not harm others [4]. While based on the opinion that assertiveness is the characterization of how a person responds in a situation where his position 
and interests may conflict with the position or interests of others [5].

Based on some expert opinions above, it can be concluded that assertive behavior is behavior between individuals or interpersonal shown by a clear, honest attitude, directly to the goal, fulfilling their own needs and still showing respect to others. Assertive behavior will be very helpful in peer relationships. Assertive behavior does not appear on its own but needs to be nurtured to develop.

Assertive behavior has several aspects that show assertive behavior, including among others. There are related aspects that exist in assertive behavior, it was stated that these aspects of assertiveness include [23]:

1) Act according to his own wishes.

Includes the ability to make decisions, take initiative, believe in what is presented by yourself, can determine a goal and try to achieve it, and able to participate in relationships.

2) Able to express honest and comfortable feelings.

Includes the ability to express disagreement, anger, show affection and friendship with others and acknowledge feelings of fear or anxiety, express agreement, show support, and be spontaneous.

3) Able to defend themselves.

Includes the ability to say "no" if needed, able to respond to criticism, criticism, and anger from others openly and able to express and maintain opinions

4) Able to express opinions

Includes the ability to express opinions or ideas, make changes, and respond to violations of himself and others

5) Do not ignore the rights of others.

Includes the ability to express criticism fairly without threatening, manipulating, intimidating, controlling, and injuring others.

In addition, there are factors that influence assertive behavior in everyone, these factors are:

1) Assertive behavior cannot be captured / read, it is possible when you reveal what is meant, there is less clarity and firmness so that others cannot catch or receive it. Sometimes assertive behavior is less pleasant and less friendly. This behavior is considered as inappropriate, considered aggressive, and eventually creates emotional tension

2) Assertive behavior is defined differently

There are a variety of different definitions of individuals in society. For example, for women assertive behavior requires consideration while for men assertive behavior as a power and influence

\section{3) Gender / gender differences}

Women's groups get judgment and attention in this assertive case. It was explained that men are said to be more assertive than a woman. Today women have begun to develop their assertive abilities to avoid discrimination for them at work or at home. This also raises the pros and cons that ultimately women are considered aggressive, women have dared to claim rights etc.

4) Situation factors

Assertiveness can of course happen better in certain situations. This explains that when you must be assertive and certainly in the right decision.

5) Cultural background

This type of assertive behavior is the value that will be received from the existing culture. A place where cultural values are built and acquired. this makes assertiveness must be placed in the appropriate situation

There are 5 factors that influence assertive behavior as follows [24]:

1) Gender

Women in general are more difficult to behave assertively such as expressing feelings of mind compared to men.

2) Self esteem

A person's beliefs also influence the ability to adapt to the environment. People who have high selfconfidence have low social anxiety, so they can express their opinions and feelings without harming others and themselves

3) Culture

Environmental demands determine the limits of behavior where the limits of behavior are appropriate to one's age, gender, and social situation.

\section{4) Type of personality}

In the same situation not all individuals respond the same. This is influenced by the type of personality. With certain personality types, someone will behave differently from individuals with other types of personality

5) Level of education

The higher the level of education of a person, the wider the perspective of one's thinking so that they can develop themselves more openly.

\section{METHODOLOGY}

This research uses a quantitative approach to type of research experiments. The design of the research was quasi experiment. It was because researchers do not control all the variables that affect the execution of experiments. The design of the research used randomized control group pretest-posttest design, aiming to view or compare the results from two 
different groups namely experimental group classes and group control class.

Purposive sampling was used to take the sample, while random assignment was used determination of the subject. This was done to determine a student's group of experimental and control group. The process of sampling was done by selecting the 12 students with assertive low behavior criteria. There were six students are male and six female students. The sample then divided randomly in a group of experimental and control group.

The data collection used the assertive behavior scale and group counseling guide of rational emotive behavior. Scaling behavior of assertive compiled by researchers based on four aspects mentioned by Alberti and Emmons [23]. Were act in accordance with his own, able to express the feelings of comfort, honest and able to defend itself, be able to state an opinion, and not ignoring the rights of others. Scale made by researchers using the Likert scale in accordance with the opinion of the Saif Azwar [26]. with 4 choices of answers that was very appropriate (SS), subject (S), it is not appropriate (TS) and not very fit (STS). The scale was presented in the form of favorable and unfavorable statement. The result of the reliability scale is 0.9 .

\begin{tabular}{lllc}
\hline Name of group & $\mathbf{Z}$ & $\mathbf{p}$ & Note \\
\hline $\begin{array}{l}\text { Post-test KE dan Post- } \\
\text { test KK }\end{array}$ & -1.363 & 0.173 & $\begin{array}{c}\text { Not } \\
\text { significant } \\
\text { significant }\end{array}$ \\
Pre-test - post-test KE & -2.207 & 0.27 & significant \\
Pre-test - post-test KK & -2.201 & 0.28 &
\end{tabular}

The data analysis in this research was Wilcoxon Mtached - pairs signed rank test, with the help of SPSS version 20.0 for windows. The purpose of this analysis was to find out the level of difference in the results of the post-test between the experimental and the control group. Based on the results of data analysis using the Wilcoxon Mtached test hypothesis - pairs signed rank tests on behavior of assertive data between the experimental and the control group showed no significant difference

\section{RESULT AND DISCUSSION}

Based on the results of the analysis of Wilcoxon Mtached-pairs signed rank test for pre-and post-testtest, known that score post-test between the control group and experimental group obtained the value of $\mathrm{p}$ $=0173(\mathrm{p}>0.05)$. Data between the experimental group and the control group showed no significant difference. The data is presented in the form of diagrams and tables as shown below:
TABLE I. RESULT OF DATA ANALYSIS

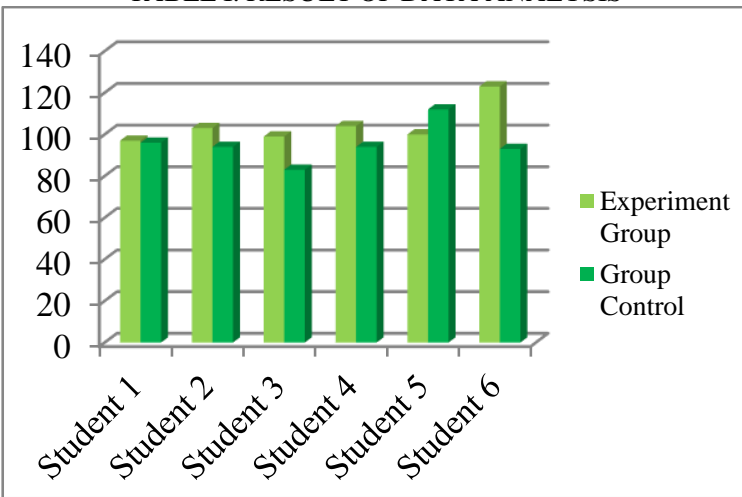

Fig 1. The result of Wilcoxon Post-test on experiment and control group

The analysis result of Wilcoxon Mtached-pairs signed rank test between the experimental and the control group that there was no significant difference between the control group and the experimental group $(\mathrm{p}=0.173)$. While the results of the analysis of Wilcoxon Mtached-pairs signed rank test for pre-and post-test-test experimental group showed a significant result which means there is a difference in behavior of asertif (0.27). While the results of the analysis Wilcoxon Mtached-pairs signed rank test for pre-test and posttest control group showed a significant result which means there is a difference in behavior of assertive (0.28)

The results showed that there was no significant difference in behavior of assertive students in the control group and experimental group. Based on the study of theoretical counseling group rational emotive behavior can improve the behavior of assertive students. But in this study showed different results, namely the insignificant means counseling group rational emotive behavior is not appropriate for the study of the behavior of assertive students to students of SMP 1 Mlati, Sleman, Yogyakarta. The results of this research are thought to be influenced by several factors. These factors are the place of counseling that is less conducive and the effectiveness of counseling time, lack of interpersonal closeness between counselor and students and the presence of other counseling techniques or approaches that can be used to improve students' assertive behavior.

Factors that influence the outcome of this research allegedly discussed theoretical studies with relevant research. Factors that affect the process of counseling group of rational emotive behavior are discussed as follows: the first factor is the place of counseling that is less conducive. Counseling held on this research originally done in guidance and counseling. However, the room was narrow and sometimes there were students who come to the space BK for consultation, thus disrupting the process of counseling because there is no covering. Finally, the teacher's guidance and counseling suggested to use the science lab. The room 
was wide but less conducive because sound becomes less clear and noises from outside sounds until into the room. Similarly, when there is a practical science room cannot be used for the process of counseling.

Given alternative was to use School Hall, the process of counseling at hall more conducive because the noise from the outside was not heard. But students feel uncomfortable when the process of counseling, because the fan turns off and there was no air conditioning, there was a positive side because there was a projector that can be used for the process of assertive training, or to play the video. The researchers could not choose their own room that will be used for the process of counseling. The selection of this counseling room was in accordance with the direction of the teacher.

The conducive and convenient room will support the success of counseling. As described by Glading, even though the group counseling varies, member requires a clarity of a consistent time and place to meet. Most of the groups met 90-120 minutes each week for 12 to 16 sessions. Meeting room subdued, supposed to make students interested in counseling and stay away from other activities. The group will be effective when the seats are arranged in a circle in which all people feel a sense of equality with each other and doing the communication [27].

Fibkins explained that the counseling process can take place in many places. The best place is where the students feel comfortable. Thus, the counselor will need to pay attention to the environment of the place of counseling. The place should be attractive and comfortable for students. This shows that the process of counseling is influenced by places or room for counseling [28].

Furthermore, was the time duration in the execution of counseling. On the process of counseling group of rational emotive behavior was conducted as many as eleven times. On the counseling process has been ongoing, counselors suspect the process of counseling has a less than ideal time, because the process of awarding of assertive training in groups only done twice. According to Latipun, short term group counseling needs 8-20 times the frequency of the meetings between one to three times a week with a duration of 60-90 seconds [14].

The third factor that cause of less effective rational emotive behavior assertive behavior towards the students was the lack of interpersonal closeness between counselors and students. Counselors and students just met when the process of counseling was conducted. Outside of the counseling session, counselors and students are not doing a lot of interaction. The student only a few times got an SMS to WhatsApp and researchers simply pool area was great. The closeness of the relationships in counseling process affect the success of counseling. The good counseling could receive a warm, positive communication and can help the success of the process of counseling. Described by Tirtawati that counseling can receive a warm, and effective in the execution of counseling requires quality interpersonal relationships between counselors and student [30]. Berg explains that a group leader should not need to have high expectation on the group to forget the important things such as feelings, acceptance and intimacy that is intertwined in the group. The opinion by explaining that intimacy with student be a means, while in this study this intimacy only as alone [31].

The fourth factor was the existence of approaches or techniques of rational emotive behavior, which is effectively used to help the behavior of assertive students. Based on previous research assertive behavior can be improved by using techniques of assertive training, role play and using guidance groups. In the control group with the person-centered approach behaviors assertive students can be increased. Person centered with unconditional positive regard; student is the subject not the object. Unconditional acceptance and empathy from the counselor make students feel comfortable while counseling.

\section{CONCLUSION}

Each student has a different level of assertive behavior. This behavior at the beginning of growth may be low, but as students develop this behavior is fostered and helped to grow. This is because of the support of a good social environment for the development of students' assertive behavior. The existence of good student assertive behavior will help students find the appropriate peer social environment. Being able to say directly without shame and fear if you have things you want to say to friends. Assertive behavior helps students to develop intrapersonal better. Assertive behavior will be used by students both in peer friendship and in the learning process in class. This is done to ask questions or convey matters related to the learning process in the classroom. Surely this assertive behavior will be very useful for further student development.

\section{REFERENCES}

[1] Desmita, Psikologi perkembangan. Bandung: PT Remaja Rosdakarya, 2005

[2] Gumbiner, Jan, Adolescent assessment. Kanada: John wiley \& sons, Inc, 2003

[3] Batubara, Jose rl., "Adolescent development (perkembangan remaja)", Sari Pediatri, Vol. 12, No. 1, 2010

[4] Lovihan, M. AK., \& Kaunang, R. O. W. Perbedaan perilaku asertif pada wanita karir yang sudah menikah dengan yang belum menikah di minahasa. INOVASI. Volume 7 Nomor 4, 2010

[5] Ames, D. Pushing up to a point: assertiveness and effectiveness in leadership and interpersonal dynamics. Research in organizatonal behavior 29. 111-113, 2009.

[6] Latipun. Psikologi konseling edisi ketiga. Malang. UMM Press, 2006 
[7] Komalasari, G., Wahyuni, E., Karsih. Teori dan teknik konseling. Jakarta. PT Indeks, 2011.

[8] Jones, R. N. Teori dan praktik konseling dan Terapi. Yogyakarta. Pustaka Pelajar, 2006.

[9] Andriana, R. Efektifitas rational emotive behavior therapy (REBT) untuk mengurangi kecemasan siswa akselerasi SMA Negeri 1 Batu. Tesis magister, tidak diterbitkan, Universitas Negeri Malang, Malang, 2012.

[10] Zionts, P \& Zionst, L. Rational emotive behavior therapy with troubled students. Reclaiming Children and Youth, 6, 103-108, 1997.

[11] Nahid, Ms. D. G. E. The impact of rational emotive behavior theraphy (rebt) on conduct disorder in adolescent students. Artikel Disertasi Doktor, tidak diterbitkan, Uniersity of Mysore, Manasagangotthri, Mysore, 2009.

[12] Warren, J. M., \& Hale, R. W. Fostering non cognitive development of underpresented students through rational emotive behavior therapy: recommendations for school counselor practice. Journal of professional counselor, volume 6, Issue1, pages 89-106

[13] Affandi, R dkk. The use of group counseling rational emotive behavior therapy (home work) technique to reduce aggressive behavior at seventh grade. Jurnal FKIP Universitas Lampung, 2016.

[14] Latipun. Psikologi konseling. Malang. UMM Press, 2001.

[15] Gunarsa, S. Konseling dan psikoterapi. Jakarta. PT BPK Gunung Mulia, 1996.

[16] Komalasari, G., Wahyuni, E., Karsih. Teori dan teknik konseling. Jakarta. PT Indeks, 2014
[17] Kurnanto, M. E. Konseling kelompok. Bandung. Alfabeta, 2013.

[18] Komalasari, G., Wahyuni, E., Karsih. Teori dan teknik konseling. Jakarta. PT Indeks, 2011.

[19] Latipun. Psikologi konseling. Malang. UMM Press, 2001.

[20] Csoti, M. Developing children's social emotional and behavioural skills. New York. Continum, 2009.

[21] Miasari, A. Hubungan antara komunikasi positif dalam keluarga dengan asertivitas pada siswa SMP Negeri 2 Depok Yogyakarta. Empathy. Vol.I No.1, 2012.

[22] Rosita, Herni. Hubungan Antara Perilaku Asertif Dengan Kepercayaan Diri Pada Mahasiswa. E-Journal Psikologi. [Online]. Link: http://publication.gunadarma.ac.id/handle/123456789/1837, 2012.

[23] Saifuddin Azwar. Penyusuana Skala Psikologi Edisi 2. Yogyakarta. Pustaka Pelajar, 2013.

[24] Glading, S. T. Effective group counseling. ERIC Counseling and Student Services Clearinghouse School of Education University of North Carolina at Greensboro Greensboro, North Carolina, 1994

[25] Fibkins, W. L. The emotional growth of teens how group counseling intervention works for schools. USA. Rowman \& Littlefield, 2014.

[26] Berg, R. C., Landerth G. L., \& Fall, Kevin. A. Group counseling concepts and procedures sixth edition. New . Routledge Taylor \& Francis Group, 2018. 